\title{
Honokiol induces autophagy and apoptosis of osteosarcoma through PI3K/Akt/mTOR signaling pathway
}

\author{
ZHIQUAN LI ${ }^{1}$, HUI DONG ${ }^{2}$, MO LI $^{1}$, YAOPING WU ${ }^{1}$, YANWU LIU ${ }^{1}$, \\ YINAN ZHAO $^{1}$, XIAOCHAO CHEN ${ }^{1}$ and MINLIANG MA ${ }^{1}$ \\ ${ }^{1}$ PLA Institute of Orthopedics and Traumatology, Xijing Hospital, The Fourth Military Medical University, Xi'an, \\ Shaanxi 710032; ${ }^{2}$ Department of Orthopedics, The 474th Hospital of PLA, Urumqi, Xinjiang 830013, P.R. China
}

Received October 21, 2016; Accepted June 8, 2017

DOI: $10.3892 / \mathrm{mmr} .2017 .8123$

\begin{abstract}
Honokiol is the main active constituent of Magnolia officinalis. With effective and long-term pharmacological functions of being antibacterial, anti-oxidative, anti-inflammatory, antitumor, anti-spasmic, anti-anxiety and anti-viral, Honokiol is clinically used in the treatment of acute enteritis and chronic gastritis. The aim of the present study was to observe the possible anti-effects of honokiol on autophagy and apoptosis of osteosarcoma, and to investigate the role of the PI3K/Akt/mTOR signaling pathway in its anticancer effects. MTT assay was used to evaluate cell proliferation and Annexin V-fluorescein isothiocyanate/propidium iodide staining flow cytometry was used to analyze the apoptotic rate. The authors identified that honokiol could inhibit cell proliferation and induce the apoptotic rate of osteosarcoma cells. The expression level of Bcl-2-like protein 4, caspase-3 and $\mathrm{p} 53$ protein expression were induced and cyclin D1 protein expression was suppressed in osteosarcoma cells by honokiol. Autophagy-associated LC3II protein expression level was promoted, and PI3K, p-Akt and p-mTOR protein expression level was suppressed in osteosarcoma cells by honokiol. The present study demonstrated, to the best of the authors' knowledge, for the first time that honokiol induces autophagy and apoptosis of osteosarcoma cells through the PI3K/Akt/mTOR signaling pathway.
\end{abstract}

\section{Introduction}

As the most common primary malignant bone tumor occurring in children and adolescents, osteosarcoma is characterized by early lung metastasis and high recurrence rate (1). Surgery,

Correspondence to: Professor Yaoping Wu, PLA Institute of Orthopedics and Traumatology, Xijing Hospital, The Fourth Military Medical University, 127 Changle West Road, Xi'an, Shaanxi 710032, P.R. China

E-mail: wenkqesfvb@163.com

Key words: honokiol, osteosarcoma, autophagy, apoptosis $\mathrm{PI} 3 \mathrm{~K} / \mathrm{Akt} / \mathrm{mTOR}$ combined with neoadjuvant chemotherapy and other comprehensive treatment approaches, can significantly improve the disease, but some local osteosarcomas still recur; at present, there have been no effective approaches for the treatment of recurrent and metastatic osteosarcoma (2). Although neoadjuvant chemotherapy combined with surgery improves the long-term survival rate of patients with osteosarcoma, short-term survival rate of patients has not been further improved in recent years (3).

Autophagy is an ancient biological phenomenon in the evolution of creatures, and extensively occurs in plants and low-ranking organisms as an important ways to maintain the stability of cellular homeostasis; autophagy is also one of the most important means by which mammals can eliminate tumor cells. Autophagy is closely related to the incidence, development, prognosis and treatment of tumor cells (4). When the body grows tumor cells, autophagy will be activated to remove damaged organelles and degrade harmful substances in cells such as peroxides, so as to prevent normal cells from developing into tumor cells (5). Some scholars observed autophagosomes wrapped parts of the nucleolus, suggesting that autophagy is involved in the metabolism of genetic materials in cells and in the elimination of mutant chromosomes (6). Regulating the expression of autophagy combined with chemotherapy drugs has synergistic or antagonistic effects in the growth of tumor cells. Compared with chemotherapy alone, the regulation autophagy changes the apoptosis rate of tumor cells (7). Inhibiting the expression of autophagy during radiotherapy or chemotherapy may cause tumor cells to be unable to eliminate damaged organelles, thereby accelerating the death of tumor cells, so as to enhance the efficacy of treatment (8).

Akt (also known as protein kinase B) is a regulator located at the downstream of the PI3K pathway. Mammalian target of rapamycin (mTOR), a kind of serine/threonine protein kinase, is a member of phosphatidylinositol 3-kinase family (9). mTOR exists in multi-protein complexes, such as mTORC1 and mTORC2. The PI3K-Akt-mTOR signaling pathway serves important roles in cells, regulating a variety of cellular behaviors such as growth, survival, proliferation, apoptosis, angiogenesis and autophagy of cells (10). Many diseases, including cancer, autoimmune diseases and neuropathy, are caused by disorders of the PI3K-Akt-mTOR signaling pathway (10). The PI3K-Akt-mTOR signaling pathway is 
related to several important mechanisms of cell growth, so a better understanding of the PI3K-Akt-mTOR signaling pathway contributes to the development of cancer drugs, and mTOR inhibitors have been previously developed and applied as novel antitumor targeting drugs (11).

As one of the two major active constituents of Magnolia officinalis, honokiol can effectively fight against bacteria, oxidation, inflammation and tumors, inhibit central nervous and muscular relaxation, kill pathogenic microorganisms and lower cholesterol levels, and is generally used in the treatment of acute enteritis, bacterial or amoebic dysentery and chronic gastritis (12). A large number of studies have demonstrated that honokiol inhibits the proliferation and apoptosis of cancer cells and prevents from angiogenesis in vivo, indicating that it has good therapeutic effect on different tumors (13). Honokiol has a better curative effect if combined with other anticancer drugs. A study suggested that Honokiol downregulates the phosphorylation of Akt and upregulates the expression of PTEN to realize the negative regulation of PI3K/Akt $/ \mathrm{mTOR}$ pathway, so as to inhibit breast cancer (14). Honokiol promoted cycle arrest and apoptosis of breast cancer cells through the downregulation of the c-Src/EGFR signaling pathway. Furthermore, the authors investigated whether honokiol induces autophagy and apoptosis of osteosarcoma, and analyzed the possible mechanisms underlying these anticancer effects.

\section{Materials and methods}

Cell culture. The human OS cell line, MG-63, was purchased from the Wuhan Cell Bank of Sciences China (Wuhan, China) and maintained in Dulbecco's modified Eagle's medium, which contains $10 \%$ heat-inactivated FBS (both from Gibco; Thermo Fisher Scientific, Inc., Waltham, MA, USA) at $37^{\circ} \mathrm{C}$ in $5 \% \mathrm{CO}_{2}$. Honokiol was purchased from Sigma-Aldrich; Merck $\mathrm{KGaA}$ (Darmstadt, Germany) and its constitutional formula is presented in Fig. 1.

MTT assay. MG-63 cells were seeded in 96-well plates at a density of $1 \times 10^{4}$ cells/well overnight and then treated with various concentrations of honokiol $(0,5,10$ and $20 \mu \mathrm{g} / \mathrm{ml})$ for 24, 48 and $72 \mathrm{~h}$. A total of $20 \mu \mathrm{l}$ MTT solution $(5 \mathrm{~g} / \mathrm{l}$; Thermo Fisher Scientific, Inc.) was added to each well and incubated for $4 \mathrm{~h}$. DMSO (Thermo Fisher Scientific, Inc.) was added to cells and dissolved for $20 \mathrm{~min}$. The absorbance value was read using an automatic multiwell spectrophotometer (PowerWave HT; Bio-Tek Instruments, Inc., Winooski, VT, USA) at $570 \mathrm{~nm}$.

Apoptosis. MG-63 cells were seeded in 6-well plates at a density of $1 \times 10^{6}$ cells/well overnight and then treated with various concentrations of honokiol $(0,5,10$ and $20 \mu \mathrm{g} / \mathrm{ml})$ for $48 \mathrm{~h}$. MG-63 cells were washed three times with PBS and stained using the Annexin V-fluorescein isothiocyanate (FITC)/propidium iodide (PI) assay (BD Biosciences, Franklin Lakes, NJ, USA) following the manufacturer's protocol. Apoptotic rate was detected using flow cytometry (FACSCanto ${ }^{\mathrm{TM}}$ ) and analyzed by CellQuest ${ }^{\mathrm{TM}}$ software (version 3.2) (both from BD Biosciences).

Caspase-3 and western blotting analysis. MG-63 cells were seeded in six-well plates at a density of $1 \times 10^{6}$ cells/well overnight and then treated with various concentrations of Honokiol $(0$, 5, 10 and $20 \mu \mathrm{g} / \mathrm{ml}$ ) for $48 \mathrm{~h}$. MG-63 cells were resuspended in radioimmunoprecipitation assay buffer (Beyotime Institute of Biotechnology, Haimen, China) at $4^{\circ} \mathrm{C}$ for $30 \mathrm{~min}$ and the lysate was centrifuged at $120,000 \mathrm{x}$ g for $10 \mathrm{~min}$ at $4^{\circ} \mathrm{C}$. Protein contents were detected using the Bicinchoninic Acid protein assay kit (Thermo Fisher Scientific, Inc.). A total of 5-10 $\mu \mathrm{g}$ protein was incubated with Ac-DEVD-pNA for $1-1.5 \mathrm{~h}$ at $37^{\circ} \mathrm{C}$. The absorbance value was read using an automatic multiwell spectrophotometer (PowerWave HT; Bio-Tek Instruments, Inc.) at $405 \mathrm{~nm}$.

Next, equal amounts of total protein $(50 \mu \mathrm{g})$ were separated on $6-12 \%$ SDS-PAGE gel and transferred to polyvinylidene difluoride membranes (Thermo Fisher Scientific, Inc.). The membranes were blocked with fat-free milk solution $(5 \%, \mathrm{w} / \mathrm{v})$ for $12 \mathrm{~h}$ and then incubated with rabbit anti- B-cell lymphoma-2 (Bcl-2, 1:500, cat no. sc-783) and anti- Bcl-2-like protein 4 (Bax, 1:500, cat no. sc-6236), p53 (cat no. sc-6243), cyclin D1 (1:500, cat no. sc-717), LC3II (1:500, cat no. sc-292354), PI3K (1:500, cat no. sc-7174), p-Akt (1:550, cat no. sc-16646-R), p-mTOR (1:500, cat no. sc-101738) and GAPDH (1:500, cat no. sc-25778) (all from Santa Cruz Biotechnology, Inc., Dallas, TX, USA) primary antibodies at $4^{\circ} \mathrm{C}$ for $12 \mathrm{~h}$. After washing 3 times with TBS and $0.1 \%$ Tween-20, membrane was incubated with horseradish peroxidase-conjugated anti-rabbit IgG antibody (1:5,000, cat no. sc-2004; Santa Cruz Biotechnology, Inc.) at $37^{\circ} \mathrm{C}$ for $1 \mathrm{~h}$ and were visualized using Western Blotting Chemiluminescence Reagent (BD Biosciences). Blots blank was quantified using BandScan software (version 5.0; Glyko Inc., Novato, CA, USA).

Statistical analysis. Data are presented as the mean \pm standard deviation. Student's t-tests were performed for the comparison of results between different groups. $\mathrm{P}<0.05$ was considered to indicate a statistically significant difference.

\section{Results}

Honokiol inhibited cell proliferation of osteosarcoma cells. As presented in Fig. 2, an MTT assay demonstrated that various concentrations of honokiol inhibited cell proliferation of osteosarcoma cells (MG-63) in a dose- and time-dependent manner. Treatment with osteosarcoma cell $(5,10$ and $20 \mu \mathrm{g} / \mathrm{ml}$ honokiol for $72 \mathrm{~h}$ ), or 10 and $20 \mu \mathrm{g} / \mathrm{ml}$ honokiol for $48 \mathrm{~h}$ or $20 \mu \mathrm{g} / \mathrm{ml}$ honokiol for $24 \mathrm{~h}$ significantly inhibited cell proliferation of MG-63 cells, compared with the control group (0 $\mu \mathrm{g} / \mathrm{ml}$ group).

Honokiol induced apoptotic rate of osteosarcoma cell. Therefore, the authors detected the apoptotic rate of osteosarcoma cells (MG-63) by honokiol for $48 \mathrm{~h}$. As demonstrated in Fig. 3, Annexin V-FITC/PI indicated that 10 and $20 \mu \mathrm{g} / \mathrm{ml}$ honokiol significantly induced apoptotic rate of MG-63 cells, compared with the control group (0 $\mu \mathrm{g} / \mathrm{ml}$ group).

Honokiol induced Bax, p53 and cyclin D1 protein expression and caspase-3 activity of osteosarcoma cells. To investigate apoptosis mechanism of Honokiol on osteosarcoma cell, the authors firstly detected Bax, p53 and cyclin D1 protein 


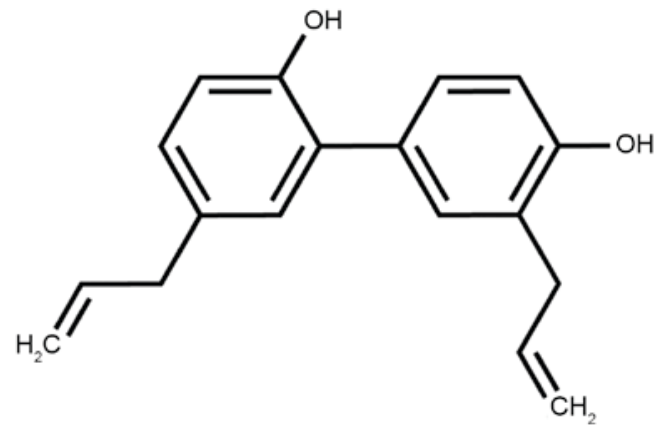

Figure 1. Constitutional formula of honokiol.

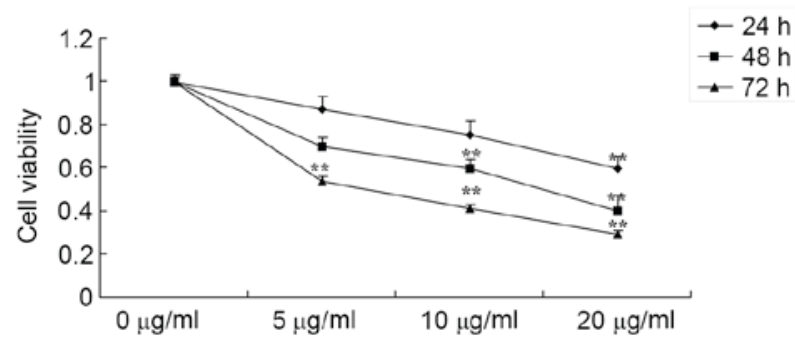

Figure 2. Honokiol inhibited cell proliferation of osteosarcoma cells Honokiol inhibited cell proliferation of osteosarcoma cells for $24 \mathrm{~h}$ and $48 \mathrm{~h}$. $0 \mu \mathrm{g} / \mathrm{ml}, 0 \mu \mathrm{g} / \mathrm{ml}$ honokiol; $5 \mu \mathrm{g} / \mathrm{ml}, 5 \mu \mathrm{g} / \mathrm{ml}$ honokiol; $10 \mu \mathrm{g} / \mathrm{ml}, 10 \mu \mathrm{g} / \mathrm{ml}$ honokiol; $20 \mu \mathrm{g} / \mathrm{ml}, 20 \mu \mathrm{g} / \mathrm{ml}$ honokiol. ${ }^{* *} \mathrm{P}<0.01 \mathrm{vs.} 0 \mu \mathrm{g} / \mathrm{ml}$ honokiol group.

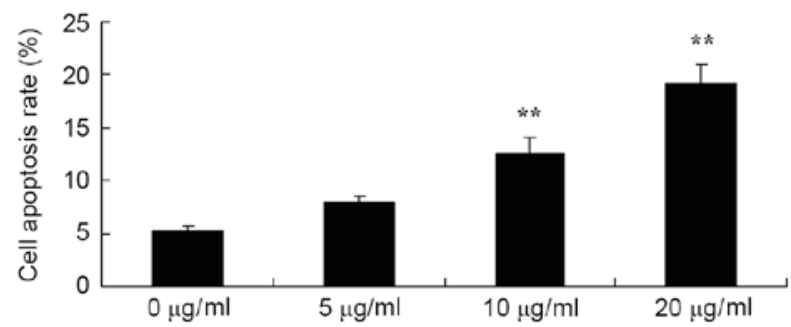

Figure 3. Honokiol induced apoptotic rate of osteosarcoma cells. $0 \mu \mathrm{g} / \mathrm{ml}$, $0 \mu \mathrm{g} / \mathrm{ml}$ honokiol; $5 \mu \mathrm{g} / \mathrm{ml}, 5 \mu \mathrm{g} / \mathrm{ml}$ honokiol; $10 \mu \mathrm{g} / \mathrm{ml}, 10 \mu \mathrm{g} / \mathrm{ml}$ honokiol; $20 \mu \mathrm{g} / \mathrm{ml}, 20 \mu \mathrm{g} / \mathrm{ml}$ honokiol. ${ }^{* *} \mathrm{P}<0.01$ vs. $0 \mu \mathrm{g} / \mathrm{ml}$ honokiol group.

expression and caspase-3 activity in osteosarcoma cell (MG-63) by honokiol for $48 \mathrm{~h}$. In Fig. 4, 10 and $20 \mu \mathrm{g} / \mathrm{ml}$ honokiol significantly induced bax and p53, and significantly inhbited cyclin D1 protein expression levels compared with the control. Honokiol treatment led to increased caspase- 3 activity of MG-63 cells, compared with the control group $(0 \mu \mathrm{g} / \mathrm{ml}$ group).

Honokiol promoted LC3, PI3K, p-Akt and p-mTOR protein expression of osteosarcoma cells. In order to test the role of autophagy in the anticancer effects of honokiol on osteosarcoma cells, LC3II protein expression of MG-63 cell was measured. Western blotting revealed that 10 and $20 \mu \mathrm{g} / \mathrm{ml}$ honokiol significantly promoted LC3 protein expression of MG-63 cell, compared with the control group $(0 \mu \mathrm{g} / \mathrm{ml}$ group; Fig. 5A and B). The authors then examined the autophagy mechanism of anticancer effects of honokiol on osteosarcoma cells. As presented in Fig. 5A and C-E, PI3K,
p-Akt and p-mTOR protein expression levels of MG-63 cells was significantly suppressed by 10 and $20 \mu \mathrm{g} / \mathrm{ml}$ honokiol in MG-63 cells, compared with the control group ( $0 \mu \mathrm{g} / \mathrm{ml}$ group).

\section{Discussion}

Osteosarcoma is the bone malignancy most commonly occurring in adolescents (15). Neoadjuvant chemotherapy significantly improves the survival rate of patients with osteosarcoma, and reduces the rate of recurrence and metastasis, but it has a poor chemotherapy effect in some patients, easy leading to recurrence and metastasis $(15,16)$. Therefore, revealing the mechanism of the incidence and development of osteosarcoma from a new perspective to fundamentally cure tumor has always been the focus and challenge in the study of orthopedics (16). The present study demonstrated that honokiol significantly inhibited cell proliferation and induced apoptotic rate of MG-63 cells.

Cell autophagy removes excessive and harmful proteins or organelles with long half-life from cells, to protect the components of cells and provide raw materials for the reconstruction, regeneration and repair of cells, thus realizing recycle and reuse of components in cells (17). Cell autophagy is closely associated with cancers through multiple signaling pathways, such as the PI3K/Akt/mTOR signaling pathway, the LKB1/AMPK/mTOR signaling pathway, the p53 signaling pathway and the BCL-2 pathway, as well as endoplasmic reticulum stress (18). In the present study, honokiol significantly induced Bax and p53 protein expression, increased caspase- 3 activity and suppressed cyclin D1 of MG-63 cells.

Cell autophagy removes excessive and harmful proteins or organelles with long half-life from cells to protect the components of cells (5). Under normal circumstances, autophagy is conducive to the survival of cells, so the dysfunction of autophagy causes many diseases, such as neurodegenerative diseases, bacterial infection, intestinal inflammation, aging and cancers $(19,20)$. In normal cells, autophagy pathways are regulated by the signaling network, which centers on mTOR (21). Nutrients and growth factors can activate the PI3K/Akt/mTOR signaling pathway, thereby inhibiting the activity of the autophagy pathway, to promote the growth and proliferation of cells (22). When cells are lacking in nutrients and growth factors, or under the condition of hypoxia and other stresses, PI3K/Akt/m TOR signaling pathways will be inhibited and thus, the autophagy pathway be activated, inhibiting cell growth and proliferation (23). The autophagy pathway basically serves the same role in tumor cells as it does in normal cells, only the PI3K/Akt/mTOR signaling pathway is damaged and interacts with other signaling pathways, which makes the autophagy pathway in tumor cells more complex (24). The current study demonstrated that honokiol significantly promoted LC3 protein expression of MG-63 cells. $\mathrm{Lv}$ et al (19) revealed that honokiol increased the expression of p62 and LC3 I in the A549 and H460 cells.

The PI3K-AKT pathway is improperly activated in various types of cancer. PI3K-AKT can be activated through two major mechanisms, such as the activation of specific nodes in pathway and the activation of receptor tyrosine kinase, so understanding the activation mechanisms of PI3K is vital for the development of effective therapies and PI3K inhibitors $(10,18)$. It is often 


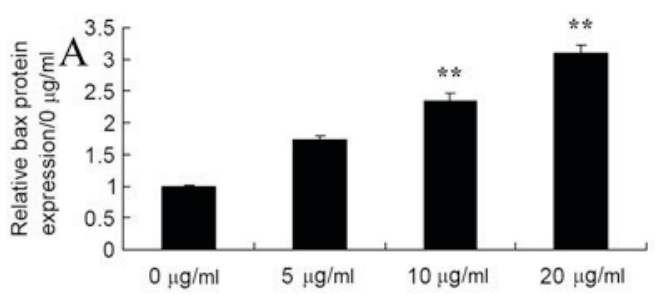

B
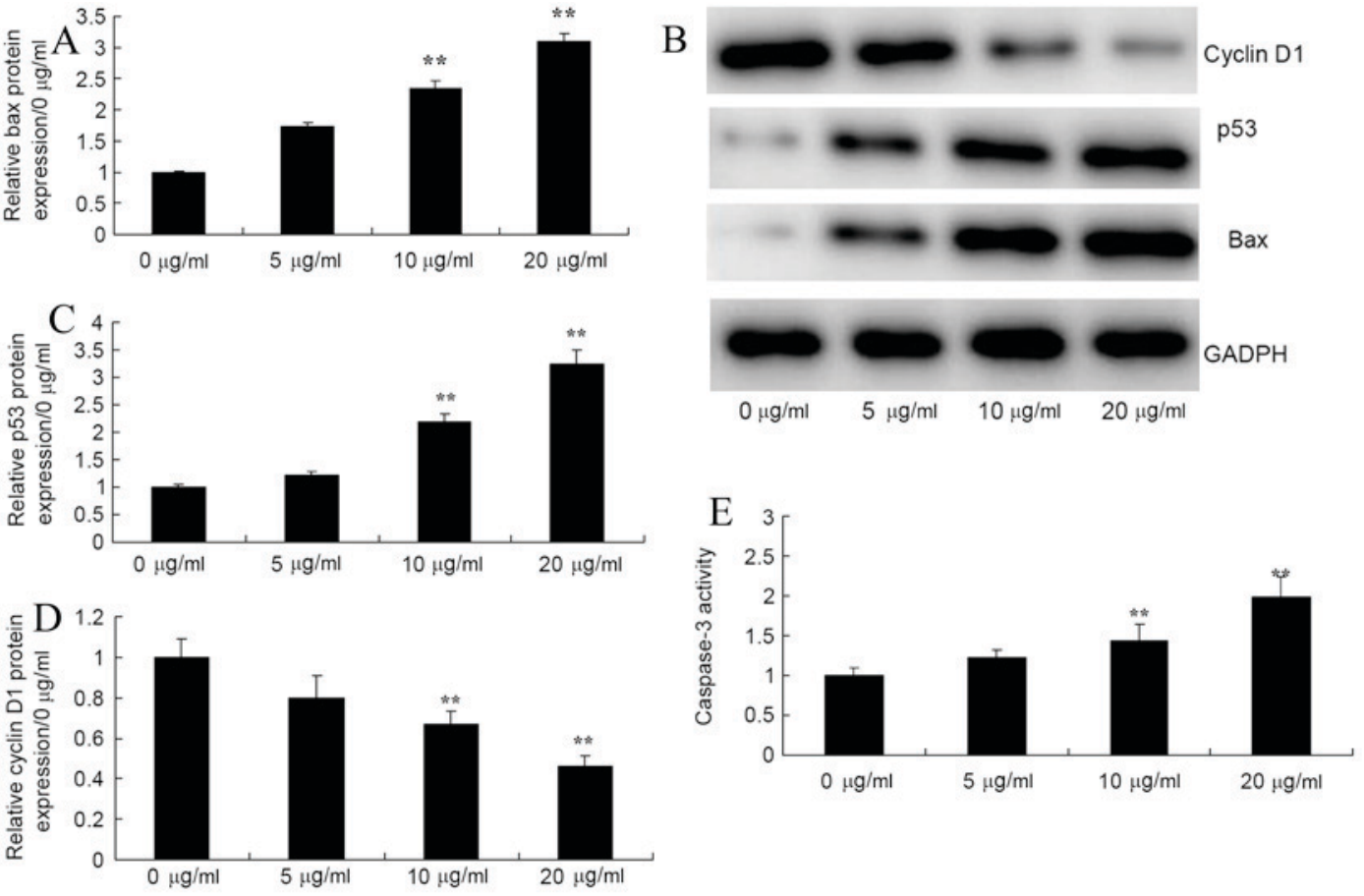

Figure 4. Honokiol induced Bax, p53 and cyclin D1 protein expression and caspase-3 activity of osteosarcoma cell. Honokiol induced (A and B) Bax, (B and C) p53 and (B and D) cyclin D1 protein expression by western blotting and statistical analysis. (E) caspase-3 activity of osteosarcoma cells. $0 \mu \mathrm{g} / \mathrm{ml}$, $0 \mu \mathrm{g} / \mathrm{ml}$ honokiol; $5 \mu \mathrm{g} / \mathrm{ml}, 5 \mu \mathrm{g} / \mathrm{ml}$ honokiol; $10 \mu \mathrm{g} / \mathrm{ml}, 10 \mu \mathrm{g} / \mathrm{ml}$ honokiol; $20 \mu \mathrm{g} / \mathrm{ml}, 20 \mu \mathrm{g} / \mathrm{ml}$ honokiol. ${ }^{* *} \mathrm{P}<0.01$ vs. $0 \mu \mathrm{g} / \mathrm{ml}$ honokiol group. Bax, B-cell lymphoma-2-associated $\mathrm{X}$ protein.
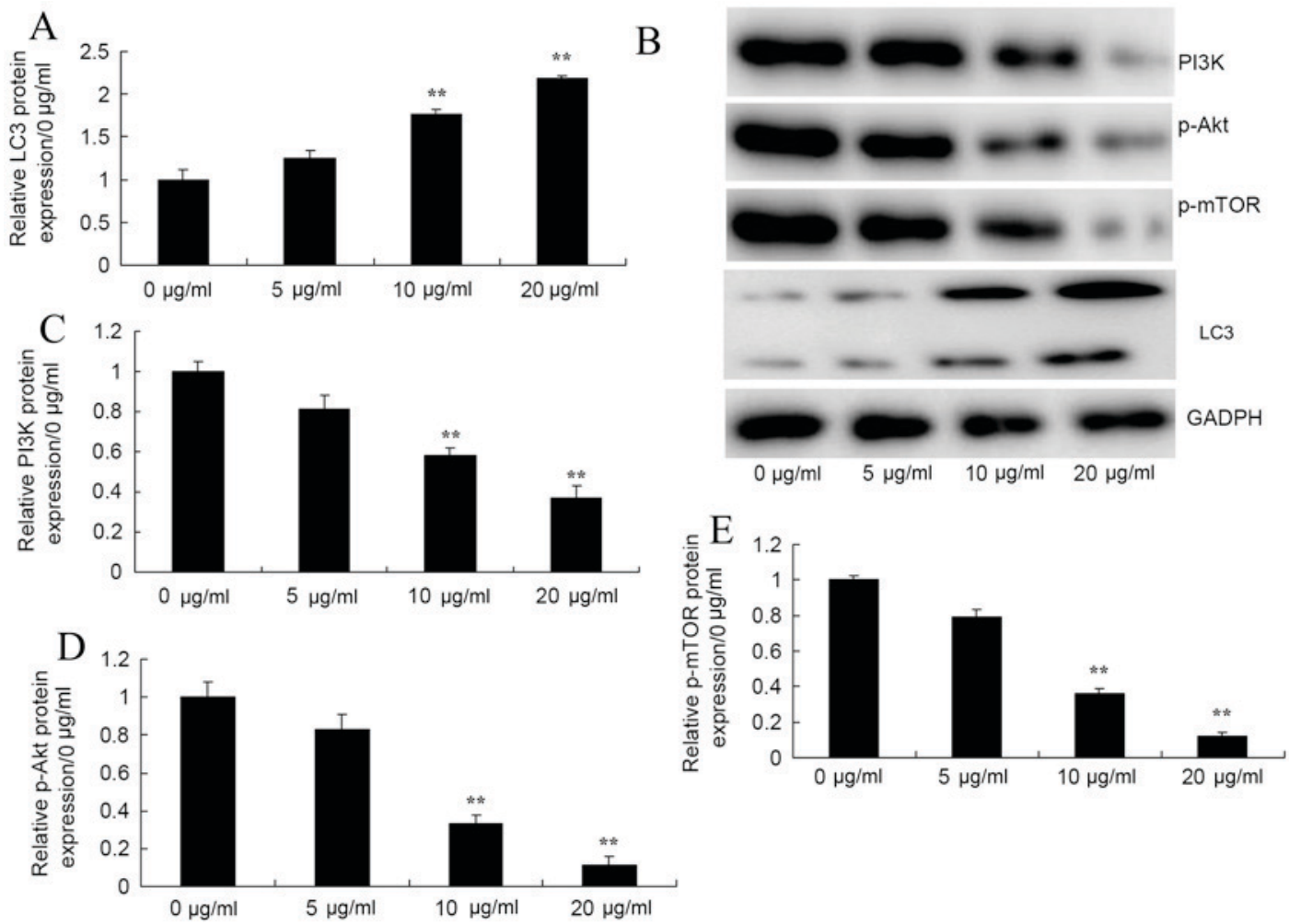

Figure 5. Honokiol promoted LC3, PI3K, p-Akt and p-mTOR protein expression of osteosarcoma cells. Honokiol induced (A and B) LC3, (B and C) PI3K, (B and D) p-Akt and (B and E) p-mTOR protein expression of osteosarcoma cells by western blotting and statistical analysis. $0 \mu \mathrm{g} / \mathrm{ml}, 0 \mu \mathrm{g} / \mathrm{ml}$ honokiol; $5 \mu \mathrm{g} / \mathrm{ml}, 5 \mu \mathrm{g} / \mathrm{ml}$ honokiol; $10 \mu \mathrm{g} / \mathrm{ml}, 10 \mu \mathrm{g} / \mathrm{ml}$ honokiol; $20 \mu \mathrm{g} / \mathrm{ml}, 20 \mu \mathrm{g} / \mathrm{ml}$ honokiol. ${ }^{* *} \mathrm{P}<0.01 \mathrm{vs} .0 \mu \mathrm{g} / \mathrm{ml}$ honokiol group. PI3K, phosphoinositide 3-kinase; p-Akt, phosphorylated protein kinase B; p-mTOR, phosphorylated mammalian target of rapamycin.

reported that the PI3K/Akt/mTOR signaling pathway works abnormally in cancer cells, and even being constitutively activated, which promotes the growth and proliferation of tumor cells (18). This may be due to one or more cellular events 
closely related to the incidence and development of cancers, such as mutation or deletion of PTEN, mutation of TSC1/2, tyrosine kinase receptor growth factor and type I PI3K, overexpression of Akt, inhibition of mTOR, exposure to carcinogens, which may lead to the activation of PI3K/Akt/mTOR, thereby inhibiting the autophagy of cells $(25,26)$. The results demonstrated that honokiol significantly suppressed PI3K, p-Akt and p-mTOR protein expression of MG-63 cell. Lin et al (27) reported that honokiol induces autophagic cell death via regulation of the $\mathrm{p} 53 / \mathrm{PI} 3 \mathrm{~K} / \mathrm{Akt} / \mathrm{mTOR}$ signaling pathway in malignant glioma (27).

In summary, the present study demonstrates, honokiol significantly inhibited cell proliferation, induced apoptotic rate, and induced Bax and p53 protein expression, increased caspase-3 activity and suppressed cyclin D1 of MG-63 cells, which may induces autophagy through the PI3K/Akt/mTOR signaling pathway. In summary, the current study indicated that honokiol may be a promising strategy for osteosarcoma therapy or clinical applications.

\section{Acknowledgements}

The present study was supported by the Natural Science Foundation Research Project of Shaanxi Province (grant no. 2014JM4120).

\section{References}

1. Nataraj V, Batra A, Rastogi S, Khan SA, Sharma MC Vishnubhatla S and Bakhshi S: Developing a prognostic model for patients with localized osteosarcoma treated with uniform chemotherapy protocol without high dose methotrexate: A single-center experience of 237 patients. J Surg Oncol 112: 662-668, 2015.

2. Tai BC, Machin D, White I and Gebski V; EOI (The European Osteosarcoma Intergroup): Competing risks analysis of patients with osteosarcoma: A comparison of four different approaches. Stat Med 20: 661-684, 2001.

3. London CA, Gardner HL, Mathie T, Stingle N, Portela R, Pennell ML, Clifford CA, Rosenberg MP, Vail DM, Williams LE, et al: Impact of toceranib/piroxicam/cyclophosphamide maintenance therapy on outcome of dogs with appendicular osteosarcoma following amputation and carboplatin chemotherapy: A multi-institutional study. PLoS One 10 e0124889, 2015.

4. Li L, Li Y, Zhao J, Fan S, Wang L and Li X: CX-5461 induces autophagy and inhibits tumor growth via mammalian target of rapamycin-related signaling pathways in osteosarcoma. Onco Targets Ther 9: 5985-5997, 2016

5. Huang Q, Ou YS, Tao Y, Yin H and Tu PH: Apoptosis and autophagy induced by pyropheophorbide-a methyl ester-mediated photodynamic therapy in human osteosarcoma MG-63 cells. Apoptosis 21: 749-760, 2016.

6. Ma K, Zhang C, Huang MY, Li WY and Hu GQ: Cinobufagin induces autophagy-mediated cell death in human osteosarcoma U2OS cells through the ROS/JNK/p38 signaling pathway. Oncol Rep 36: 90-98, 2016.

7. Zhang B, Yu X and Xia H: The flavonoid luteolin enhances doxorubicin-induced autophagy in human osteosarcoma U2OS cells. Int J Clin Exp Med 8: 15190-15197, 2015.

8. Zhou J, Wu S, Chen Y, Zhao J, Zhang K, Wang J and Chen S: microRNA-143 is associated with the survival of ALDH1 ${ }^{+} \mathrm{CD}_{133}{ }^{+}$ osteosarcoma cells and the chemoresistance of osteosarcoma. Exp Biol Med (Maywood) 240: 867-875, 2015.

9. Hu K, Dai HB and Qiu ZL: mTOR signaling in osteosarcoma: Oncogenesis and therapeutic aspects (Review). Oncol Rep 36: 1219-1225, 2016

10. Zhang J, Yu XH, Yan YG, Wang $C$ and Wang WJ: PI3K/Akt signaling in osteosarcoma. Clin Chim Acta 444: 182-192, 2015.
11. Wang Y, Sun Y, Wu Y and Zhang J: Cucurbitacin E inhibits osteosarcoma cells proliferation and invasion through attenuation of PI3K/AKT/mTOR signaling. Biosci Rep: pii: BSR20160165, 2016.

12. Averett C, Bhardwaj A, Arora S, Srivastava SK, Khan MA, Ahmad A, Singh S, Carter JE, Khushman M and Singh AP: Honokiol suppresses pancreatic tumor growth, metastasis and desmoplasia by interfering with tumor-stromal cross-talk. Carcinogenesis 37: 1052-1061, 2016.

13. Herrmann D, Schreiber A, Ciotkowska A, Strittmatter F, Waidelich R, Stief CG, Gratzke C and Hennenberg M: Honokiol, a constituent of Magnolia species, inhibits adrenergic contraction of human prostate strips and induces stromal cell death. Prostate Int 2: 140-146, 2014

14. Crane C, Panner A, Pieper RO, Arbiser J and Parsa AT: Honokiol-mediated inhibition of $\mathrm{PI} 3 \mathrm{~K} / \mathrm{mTOR}$ pathway: A potential strategy to overcome immunoresistance in glioma, breast, and prostate carcinoma without impacting $\mathrm{T}$ cell function. J Immunother 32: 585-592, 2009.

15. Felgenhauer JL, Nieder ML, Krailo MD, Bernstein ML, Henry DW, Malkin D, Baruchel S, Chuba PJ, Sailer SL, Brown K, et al: A pilot study of low-dose anti-angiogenic chemotherapy in combination with standard multiagent chemotherapy for patients with newly diagnosed metastatic Ewing sarcoma family of tumors: A Children's Oncology Group (COG) Phase II study NCT00061893. Pediatr Blood Cancer 60: 409-414, 2013.

16. Altaf S, Enders F, Jeavons E, Krailo M, Barkauskas DA, Meyers $\mathrm{P}$ and Arndt C: High-BMI at diagnosis is associated with inferior survival in patients with osteosarcoma: A report from the children's oncology group. Pediatr Blood Cancer 60: 2042-2046, 2013.

17. Yang C, Shogren KL, Goyal R, Bravo D, Yaszemski MJ and Maran A: RNA-dependent protein kinase is essential for 2-methoxyestradiol-induced autophagy in osteosarcoma cells. PLoS One 8: e59406, 2013.

18. Niu NK, Wang ZL, Pan ST, Ding HQ, Au GH, He ZX, Zhou ZW, Xiao G, Yang YX, Zhang X, et al: Pro-apoptotic and pro-autophagic effects of the Aurora kinase A inhibitor alisertib (MLN8237) on human osteosarcoma U-2 OS and MG-63 cells through the activation of mitochondria-mediated pathway and inhibition of p38 MAPK/PI3K/Akt/mTOR signaling pathway. Drug Des Devel Ther 9: 1555-1584, 2015.

19. Lv X, Liu F, Shang Y and Chen SZ: Honokiol exhibits enhanced antitumor effects with chloroquine by inducing cell death and inhibiting autophagy in human non-small cell lung cancer cells. Oncol Rep 34: 1289-1300, 2015.

20. Zhang H, Guo M, Chen JH, Wang Z, Du XF, Liu PX and Li WH: Osteopontin knockdown inhibits av, b3 integrin-induced cell migration and invasion and promotes apoptosis of breast cancer cells by inducing autophagy and inactivating the PI3K/Akt/mTOR pathway. Cell Physiol Biochem 33: 991-1002, 2014.

21. Li Y, Liu Y, Shi F, Cheng L and She J: Knockdown of Rap1b enhances apoptosis and autophagy in gastric cancer cells via the PI3K/Akt/mTOR pathway. Oncol Res 24: 287-293, 2016.

22. Bai H, Li H, Li W, Gui T, Yang J, Cao D and Shen K: The $\mathrm{PI} 3 \mathrm{~K} / \mathrm{AKT} / \mathrm{mTOR}$ pathway is a potential predictor of distinct invasive and migratory capacities in human ovarian cancer cell lines. Oncotarget 6: 25520-25532, 2015.

23. Roy R, Singh SK, Chauhan LK, Das M, Tripathi A and Dwivedi PD: Zinc oxide nanoparticles induce apoptosis by enhancement of autophagy via PI3K/Akt/mTOR inhibition. Toxicol Lett 227: 29-40, 2014.

24. Kumar D, Das B, Sen R, Kundu P, Manna A, Sarkar A, Chowdhury C, Chatterjee M and Das P: Andrographolide analogue induces apoptosis and autophagy mediated cell death in U937 cells by inhibition of PI3K/Akt/mTOR pathway. PLoS One 10: e0139657, 2015.

25. Xishan Z: Peer review report 1 on 'P53 suppresses cell proliferation, metastasis, and angiogenesis of osteosarcoma through inhibition of the PI3K/AKT/mTOR pathway'. Int J Surg 13 (Suppl 1): S32, 2015

26. Liu Y, Bi T, Dai W, Wang G, Qian L, Shen G and Gao Q: Lupeol induces apoptosis and cell cycle arrest of human osteosarcoma cells through PI3K/AKT/mTOR pathway. Technol Cancer Res Treat 15: NP16-NP24, 2016.

27. Lin CJ, Chen TL, Tseng YY, Wu GJ, Hsieh MH, Lin YW and Chen RM: Honokiol induces autophagic cell death in malignant glioma through reactive oxygen species-mediated regulation of the p53/PI3K/Akt/mTOR signaling pathway. Toxicol Appl Pharmacol 304: 59-69, 2016. 